\title{
GALACTOSE AND GLUCOSE TOLERANCE IN NORMALS, THE OBESE, AND POST-GASTRECTOMY PATIENTS
}

\author{
BY \\ S. DISCHE, W. P. STAMM, AND R. B. GOUDIE \\ From the Royal Air Force Institute of Pathology and Tropical Medicine
}

(RECEIVED FOR PUBLICATION OCTOBER 10, 1957)

The interpretation of oral glucose tolerance tests is complicated by varying individual rates of absorption from the intestinal tract. Intravenous tests eliminate the absorption factor, but there is evidence that they may be less sensitive than oral tests in detecting impaired tolerance (Moyer and Womack, 1950).

It was considered that a galactose tolerance test performed in parallel with a glucose tolerance test would indicate the rate of absorption of glucose, since there is evidence that galactose and glucose are absorbed similarly but differ in the manner of removal from the blood.

The rates of absorption of galactose and glucose are independent of the amount of sugar present once a certain concentration is reached (Cori, 1925 ; Groen, 1937). When a mixture of the two sugars is given, the total maximum rate of absorption of the two together approximates the maximum rate of absorption of either when given alone (Cori, 1926).

The actual rate of absorption of galactose is slightly greater than that of glucose, the ratio 110 : 100 being reported by Cori (1925) in rats and 118 : 100 by Groen (1937) in man. No other sugar shows a rate of absorption so closely resembling that of glucose. Fructose is absorbed at half the rate, and " unphysiological sugars," such as rhamnose and xylose, at one-tenth of the rate of glucose (Cori, 1925; Groen, 1937). The energy required for absorption (Darlington and Quastel, 1953) and the degree of depression of intestinal absorption by phloridzin (Öhnell and Höber, 1939) are the same for each sugar.

On a normal diet only minute quantities of galactose can be demonstrated in blood or urine, but when more than $20 \mathrm{~g}$. of galactose is given by mouth the sugar can easily be demonstrated in both the blood and urine of most individuals so tested (Harding and Van Nostrand, 1929).

In thyrotoxicosis oral galactose and glucose tolerance tests show impairment although intra- venous tests are normal, findings which are attributed to an increased rate of absorption of all sugars in the small intestine (Althausen, Lockhart, and Soley, 1940 ; Barnes and King, 1943). Thyroxine has been shown to have such an effect in animals (Althausen and Stockholm, 1938).

Hypothyroidism (Stenstam, 1946), pernicious anảemia (Stenstam, 1946), sprue, and vitamin B deficiency (Beams, Free, and Glenn, 1941) are all conditions in which oral galactose tolerance tests show flat curves. The flat curves are attributed to impaired absorption of galactose (Beams et al., 1941 ; Stenstam, 1946) and are paralleled by similar curves in oral glucose tolerance tests performed in the same conditions. Normal or impaired tolerance curves are found when glucose or galactose is administered intravenously.

Removal of galactose from the blood is largely effected by the liver (Bollman, Mann, and Power, 1935), and diseases causing impaired liver function are associated with reduction of galactose tolerance. Bauer (1906) was the first to describe the use of galactose in a test of liver function, and based his index of tolerance on the amount excreted in the urine after oral administration. More recently most workers have preferred to use blood levels (Althausen et al., 1940 ; MacLagan, 1940 ; Stenstam, 1946).

Galactose tolerance has been investigated in diabetes mellitus by Kosterlitz (1933) (seven cases), Althausen et al. (1940) (15 cases), and MacLagan (1940) (six cases). In only one case was tolerance found to be impaired. Alsev (1952) estimated lactate and pyruvate levels after galactose administration in 10 normals and $\mathbf{1 0}$ diabetics. Levels rose in both groups to the same degree and it was concluded that galactose metabolism proceeded normally in diabetics.

Although the removal of galactose from the blood by the liver seems unaffected by insulin, transport across cell membranes can be increased by it (Levine, Goldstein, Huddlestun, and Klein, 
1950 ; Park and Johnson, 1955). In these experiments a high dosage of insulin has been employed ; in those based on a perfusion technique the concentration of insulin used has been as much as $1 \mathrm{unit} / \mathrm{ml}$. When this is compared with the daily requirements of less than $1 \mathrm{unit} / \mathrm{kg}$. in the pancreatectomized man (Goldner and Clark, 1944 ; Ricketts, Brunschwig, and Knowlton, 1945) and when the results of galactose tolerance tests in diabetics are considered, it seems reasonable to conclude that the effect of insulin has no significance in the clinical assessment of galactose tolerance.

On the evidence available it seemed possible that galactose tolerance curves would provide the necessary evidence on the rate of glucose absorption in patients with normal liver function. In this paper are reported the results of parallel glucose and galactose tolerance tests in normal, obese, and post-gastrectomy subjects, and the significance of the findings is discussed.

The investigation was extended to obese subjects because of the reported high incidence of obesity in newly diagnosed diabetics (Joslin, Root, White, and Marble, 1952) and because of our own finding of a high incidence of obesity in patients with symptomless glycosuria and borderline glucose tolerance curves. Post-gastrectomy patients were investigated because they have been considered to show an early rapid absorption of glucose (Smith, Fraser, Staynes, and Wilcox, 1953) and should therefore provide suitable material for the investigation of the idea that galactose tolerance tests will indicate the rate of glucose absorption.

\section{Material}

A series of 37 "normal" subjects (aged 16-45 years) was investigated with both glucose and galactose tolerance tests. All were ambulant, apyrexial, and receiving no medication. Twenty-six were laboratory staff, seven were psychiatric outpatients, and the rest were suffering from minor eye or E.N.T. complaints. Their weights ranged from 112 to $204 \mathrm{lb}$. (82 to $115 \%$ expected weight).

Seven post-gastrectomy patients (aged 30-52 years) were similarly investigated. All except one were fit and were either free from or only suffered to a minimal degree from the symptoms which commonly follow this operation. The exception was under treatment for pulmonary tuberculosis.

Both tests were also performed on 18 normal obese individuals aged 17-47. The criteria of obesity were (1) weight exceeding that expected for height, age, and sex by more than $15 \%$; (2) clinical appearance of obesity. Employing these criteria it was found necessary to create a "borderline obese" group for subjects who either exceeded $115 \%$ expected weight but did not appear obese, or, being below this figure, did appear obese. A further six subjects were included in this group, four for the former reason and two for the latter.

The 18 obese subjects varied in weight from 120 to $166^{\circ}$ of that expected for height, age, and sex. Only one of these was referred because of obesity; he otherwise presented no abnormal symptoms or physical signs. Four were in-patients being treated for minor localized disorders of skin or eye. One was a short-stay patient in the psychiatric department. The remaining 13 were specially asked to attend, their obesity being noted on examination of medical records at two R.A.F. stations.

All subjects except two in the "borderline-obese" group were male.

\section{Methods}

A glucose tolerance test was performed on all cases in the morning after an overnight fast, following three days' preparatory diet containing $300 \mathrm{~g}$. carbohydrate each day with normal fat and protein. The diet on the day of the glucose test was adjusted to conform with the diet of the preceding three days. The galactose test was performed similarly on the day following the glucose test. During the whole period the galactose intake was controlled to 5 to $10 \mathrm{~g}$. daily by restricting milk to $\frac{1}{2}$ to 1 pint daily. Smoking was prohibited on the morning of the tests, and during each test the patients were sitting in a quiet room on their own. None of the patients experienced any diffculty in drinking the sugar solution and none complained of any nausea.

Performance of Glucose Tolerance Test.-The subject emptied his bladder. Duplicate fasting blood specimens were taken. Fifty grams of glucose were administered dissolved in $250 \mathrm{ml}$. of water flavoured with $1 \mathrm{ml}$. of tinct. auranti B.P.C. Blood samples were taken for two hours at 15-minute intervals from the normal and obese subjects and at 30-minute intervals from the post-gastrectomy patients. Capillary blood was used and " true " glucose was estimated by a modification of the Folin and Wu method (Dische, 1955). The fasting urine and specimens at one and two hours were tested for glucose with Benedict's reagent and for ketone bodies with Rothera's reagent.

Performance of Galactose Tolerance Test.-A venous sample of blood was taken from the patient and he was given $40 \mathrm{~g}$. of galactose in $250 \mathrm{ml}$. of water flavoured with orange essence. Warming was required to speed the solution of the galactose, but when administered it was at room temperature. Capillary blood specimens were taken at 15-minute intervals for two hours.

Estimation of Blood Galactose.-Galactose, like glucose, is a reducing agent, and all the methods described for glucose estimation utilizing this quality may be employed for galactose. The problem in esti- 
mating blood galactose levels is to distinguish reduction due to galactose from that due to glucose. The most widely used technique has been the destruction of glucose before direct estimation of galactose. Yeasts are employed to destroy the sugars selectively ; nearly all varieties of ordinary baker's yeast will readily destroy glucose and leave galactose intact (MacLagan, 1940). Allowance must be made for the non-sugar reducing substances in blood.

A number of difficulties arise in using a fermentation method. Yeasts may degenerate and there may be incomplete destruction of glucose. Occasionally yeasts may be encountered which will destroy galactose ; such yeasts may be produced with ease in the laboratory (Harding and Grant, 1933). Yeasts have reducing substances adherent to them. which may be completely removed by three washings in water, but on occasion, in our experience, they persist even in spite of many further washings. There is also the possibility that the yeast will contribute some substance which will affect the reducing power of galactose.

In order to guard against these contingencies a modified technique based on King (1951) was used. A venous sample of blood is obtained as the fasting specimen and three samples of it are diluted in sodium sulphate-sodium tungstate solution. The first acts as a blank. Galactose is incorporated into the diluent of the second and third samples so as to create internal standards of 50 and $100 \mathrm{mg} . / 100 \mathrm{ml}$. Use of such internal standards guards against and, where changes are small, compensates for all the eventualities discussed above.

TABLE I

PEAK BLOOD GALACTOSE LEVELS IN GALACTOSE TOLERANCE TEST IN NORMAL, OBESE, BORDERLINE OBESE, AND POST-GASTRECTOMY SUBJECTS

\begin{tabular}{|c|c|c|c|c|c|c|c|}
\hline $\begin{array}{l}\text { Type of } \\
\text { Subject }\end{array}$ & 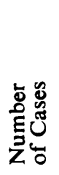 & 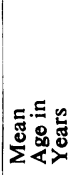 & 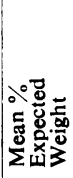 & 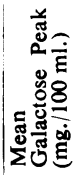 & 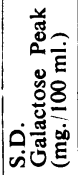 & 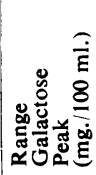 & 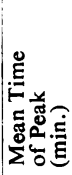 \\
\hline \multirow{5}{*}{ 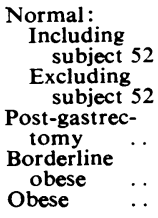 } & 37 & 23 & 101 & 65 & $29 \cdot 6$ & $15-152$ & 53 \\
\hline & 36 & 23 & 101 & 62 & $24 \cdot 8$ & $15-110$ & 53 \\
\hline & 7 & 41 & 84 & 114 & $12 \cdot 8$ & $97-130$ & 34 \\
\hline & 6 & 28 & 117 & 40 & $26 \cdot 0$ & $19-90$ & 58 \\
\hline & 18 & 28 & 137 & 31 & $22 \cdot 8$ & $0-76$ & 41 \\
\hline
\end{tabular}

By experiment it was found that galactose solutions in water readily deteriorate but those in saturated benzoic acid keep indefinitely. The presence of benzoic acid in no way interferes with the action of yeast. A blood glucose concentration of $3,000 \mathrm{mg}$./

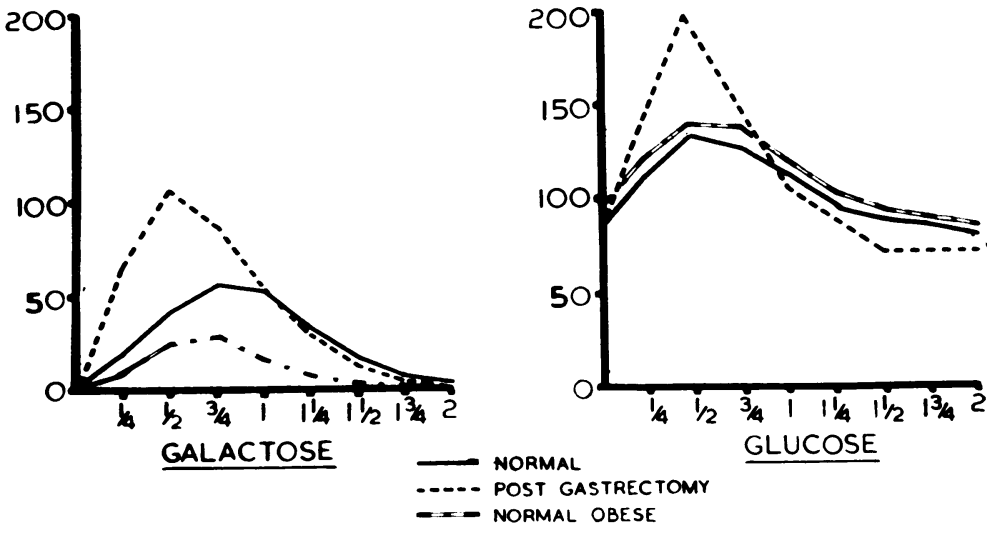

FIG. 1.-Composite blood galactose and blood glucose tolerance curves in normal and obese individuals and in post-gastrectomy patients. Ordinates: level of blood sugar in $\mathrm{mg} .100 \mathrm{ml}$.
Abscissae: time in hours after ingestion of sugar.

$100 \mathrm{ml}$. was completely destroyed in 10 minutes when benzoic acid was present in saturated solution. In the method employed the concentration of benzoic acid in the standards was $1 / 30$ of this.

Although an arteriovenous difference has been demonstrated by Harding and Grant (1933), capillary and venous samples of blood have been employed in

TABLE II

RESULTS OF GLUCOSE TOLERANCE TESTS IN 37 NORMAL CONTROLS

\begin{tabular}{|c|c|c|c|c|}
\hline & & \multicolumn{3}{|c|}{ "True" Capillary Blood Glucose } \\
\hline & & $\begin{array}{c}\text { Mean } \\
(\mathrm{mg} .100 \mathrm{ml} .)\end{array}$ & $\underset{(\mathrm{mg} . / 100 \mathrm{ml} .)}{\text { Range }}$ & $\begin{array}{c}\text { Standard } \\
\text { Deviation } \\
(\mathrm{mg} \cdot 100 \mathrm{ml} .)\end{array}$ \\
\hline $\begin{array}{l}\text { Fasting } \\
\text { Peak } \\
\text { Two-hour } \quad . \\
\text { Time of peak }\end{array}$ & $\begin{array}{l}\cdots \\
\cdots \\
\cdots \\
\cdots\end{array}$ & $\begin{array}{c}87 \cdot 8 \\
138 \cdot 9 \\
81 \cdot 1 \\
35 \mathrm{~min} .\end{array}$ & $\begin{array}{c}65-107 \\
112-166 \\
54-124 \\
15-60 \mathrm{~min} .\end{array}$ & $\begin{array}{c}8 \cdot 6 \\
14 \cdot 4 \\
12 \cdot 9 \\
11 \cdot 3 \mathrm{~min} .\end{array}$ \\
\hline
\end{tabular}

TABLE III

COMPARISON OF NORMAL GALACTOSE RESULTS IN DIFFERENT SERIES

\begin{tabular}{|c|c|c|c|c|c|}
\hline Worker & Year & $\begin{array}{c}\text { Number } \\
\text { in } \\
\text { Series }\end{array}$ & $\begin{array}{c}\text { Interval } \\
\text { between } \\
\text { Samples } \\
\text { (min.) }\end{array}$ & $\begin{array}{l}\text { Highest } \\
\text { Peak } \\
\text { (mg. } \\
100 \mathrm{ml} .)\end{array}$ & $\begin{array}{c}\text { Average } \\
\text { Peak } \\
\text { (mg./ } \\
100 \mathrm{ml} .)\end{array}$ \\
\hline 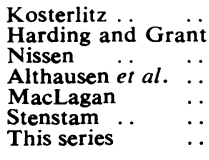 & $\begin{array}{l}1933 \\
1933 \\
1937 \\
1940 \\
1940 \\
1946\end{array}$ & $\begin{array}{l}11 \\
16 \\
20 \\
10 \\
50 \\
20 \\
37\end{array}$ & $\begin{array}{l}30 \\
15 \\
15 \\
30 \\
30 \\
20 \\
15\end{array}$ & $\begin{array}{r}63 \\
65 \\
108 \\
31 \\
81 \\
108 \\
152\end{array}$ & $\begin{array}{l}58 \\
65\end{array}$ \\
\hline
\end{tabular}


galactose tolerance tests indiscriminately (MacLagan, 1940). Capillary levels have been used for galactose determinations throughout the present study.

The details of the method are shown in the Appendix.

\section{Results of Galactose Tolerance Tests}

Composite curves showing the mean galactose values for the normal controls, post-gastrectomy patients, and the obese are shown in Fig. 1. The important values with their statistical analyses are given in Table I. One subject (No. 52) showed an elevated galactose tolerance curve with a peak value greatly exceeding those obtained in the remainder; it was greater by three standard deviations than the mean of the peak values obtained in the remaining 36 subjects. The glucose tolerance result was within normal limits. A repeat galactose test showed a similarly elevated curve. Physical examination and liver function tests failed to reveal any abnormality. Stenstam (1946) reported similar findings in two fit young women. The results are shown in Table $\mathrm{I}$, including and excluding subject 52 . All statistical calculations of significance have been based on the figures including subject 52. Galactose indices (sum of all readings) were calculated but were found to be so closely correlated with peak values that for the sake of simplicity only peak values are reported.

The peak values of the post-gastrectomy series were significantly higher than those of the normals $(P<0.001)$.

The peak values of the obese series were significantly lower than those of the normals $(P<0.001)$, and the borderline obese group all showed low normal peaks except one.

The data on the normal and obese series have been examined statistically for association with body weight within each group. The height of the peak was found to be independent of body weight, but in the normal series the time of the peak appeared to be earlier, the greater the body weight $(\mathrm{r}=-0.42, P<0.02)$.

\section{Results of Glucose Tolerance Test}

Composite glucose tolerance curves in the normals, post-gastrectomy patients, and the obese are shown in Fig. 1.

TABLE IV

RESULTS OF PARALLEL GALACTOSE AND GLUCOSE TOLERANCE TESTS IN 37 NORMAL SUBJECTS

\begin{tabular}{|c|c|c|c|c|c|c|c|c|c|c|c|c|c|c|c|c|c|c|c|c|c|}
\hline \multirow{2}{*}{$\begin{array}{l}\text { Case } \\
\text { No. }\end{array}$} & \multirow{2}{*}{ Age } & \multirow{2}{*}{ Weight } & \multirow{2}{*}{$\begin{array}{l}\text { Expected } \\
\text { Weight }\end{array}$} & \multirow{2}{*}{$\begin{array}{c}\% \\
\text { Expected } \\
\text { Weight }\end{array}$} & \multicolumn{8}{|c|}{$\begin{array}{c}\text { Galactose Tolerance Test } \\
\text { (mg. } 100 \mathrm{ml} \text {. Blood at } 15-\mathrm{min} \text {. Intervals) }\end{array}$} & \multicolumn{9}{|c|}{$\begin{array}{c}\text { Glucose Tolerance Tests } \\
\text { (mg./100 ml. Blood at } 15-\mathrm{min} \text {. Intervals) }\end{array}$} \\
\hline & & & & & 15 & 30 & 45 & 60 & 75 & 90 & 105 & 120 & F. & 15 & 30 & 45 & 60 & 75 & 90 & 105 & 120 \\
\hline $\begin{array}{r}1 \\
2 \\
3 \\
4 \\
5 \\
6 \\
7 \\
8 \\
9 \\
10 \\
11 \\
12 \\
13 \\
14 \\
15 \\
16 \\
17 \\
18 \\
19 \\
20 \\
21 \\
22 \\
23 \\
24 \\
25 \\
26 \\
27 \\
28 \\
29 \\
30 \\
31 \\
32 \\
33 \\
34 \\
35 \\
36 \\
37\end{array}$ & $\begin{array}{l}34 \\
29 \\
19 \\
16 \\
20 \\
19 \\
21 \\
22 \\
21 \\
19 \\
19 \\
26 \\
19 \\
26 \\
19 \\
19 \\
20 \\
35 \\
45 \\
39 \\
16 \\
21 \\
40 \\
22 \\
20 \\
20 \\
22 \\
18 \\
19 \\
23 \\
22 \\
26 \\
18 \\
18 \\
22 \\
23 \\
18\end{array}$ & $\begin{array}{l}120 \\
156 \\
172 \\
112 \\
145 \\
170 \\
146 \\
171 \\
154 \\
154 \\
140 \\
150 \\
154 \\
128 \\
160 \\
141 \\
129 \\
178 \\
150 \\
188 \\
175 \\
155 \\
141 \\
173 \\
138 \\
138 \\
161 \\
160 \\
132 \\
170 \\
135 \\
177 \\
204 \\
143 \\
135 \\
157 \\
157\end{array}$ & $\begin{array}{l}140 \\
150 \\
160 \\
114 \\
136 \\
161 \\
144 \\
173 \\
170 \\
146 \\
160 \\
164 \\
154 \\
150 \\
140 \\
138 \\
140 \\
156 \\
158 \\
168 \\
154 \\
153 \\
153 \\
150 \\
138 \\
144 \\
154 \\
144 \\
134 \\
164 \\
139 \\
156 \\
181 \\
144 \\
144 \\
151 \\
158\end{array}$ & $\begin{array}{r}82 \\
104 \\
107 \\
99 \\
107 \\
105 \\
101 \\
99 \\
91 \\
105 \\
88 \\
92 \\
100 \\
85 \\
114 \\
102 \\
92 \\
114 \\
95 \\
112 \\
113 \\
101 \\
92 \\
115 \\
100 \\
96 \\
104 \\
111 \\
99 \\
104 \\
97 \\
113 \\
113 \\
99 \\
94 \\
104 \\
100\end{array}$ & $\begin{array}{r}10 \\
21 \\
12 \\
15 \\
2 \\
12 \\
19 \\
9 \\
17 \\
18 \\
4 \\
18 \\
32 \\
42 \\
20 \\
15 \\
0 \\
12 \\
10 \\
9 \\
21 \\
26 \\
7 \\
6 \\
30 \\
8 \\
18 \\
27 \\
48 \\
27 \\
13 \\
33 \\
10 \\
14 \\
11 \\
72 \\
39\end{array}$ & \begin{tabular}{|r}
23 \\
32 \\
18 \\
23 \\
38 \\
46 \\
43 \\
8 \\
50 \\
48 \\
13 \\
47 \\
77 \\
70 \\
42 \\
32 \\
2 \\
43 \\
68 \\
45 \\
55 \\
44 \\
9 \\
33 \\
48 \\
50 \\
64 \\
61 \\
77 \\
46 \\
41 \\
29 \\
17 \\
38 \\
32 \\
72 \\
122
\end{tabular} & $\begin{array}{r}41 \\
42 \\
13 \\
28 \\
60 \\
67 \\
66 \\
15 \\
69 \\
77 \\
27 \\
88 \\
102 \\
110 \\
67 \\
53 \\
13 \\
77 \\
93 \\
84 \\
45 \\
70 \\
9 \\
21 \\
90 \\
52 \\
72 \\
52 \\
92 \\
61 \\
48 \\
41 \\
9 \\
66 \\
48 \\
85 \\
148\end{array}$ & $\begin{array}{r}43 \\
54 \\
19 \\
48 \\
67 \\
81 \\
51 \\
13 \\
57 \\
78 \\
31 \\
80 \\
104 \\
89 \\
71 \\
46 \\
2 \\
59 \\
105 \\
91 \\
13 \\
45 \\
15 \\
9 \\
77 \\
49 \\
65 \\
44 \\
87 \\
43 \\
51 \\
41 \\
0 \\
58 \\
71 \\
85 \\
152\end{array}$ & \begin{tabular}{|r}
31 \\
17 \\
14 \\
64 \\
52 \\
69 \\
17 \\
2 \\
29 \\
54 \\
30 \\
22 \\
66 \\
41 \\
32 \\
24 \\
0 \\
23 \\
79 \\
38 \\
19 \\
20 \\
25 \\
2 \\
42 \\
55 \\
56 \\
32 \\
66 \\
26 \\
34 \\
24 \\
0 \\
27 \\
77 \\
45 \\
134
\end{tabular} & $\begin{array}{r}15 \\
5 \\
2 \\
15 \\
19 \\
49 \\
4 \\
2 \\
13 \\
34 \\
24 \\
6 \\
31 \\
10 \\
10 \\
0 \\
15 \\
12 \\
41 \\
16 \\
12 \\
16 \\
10 \\
0 \\
16 \\
28 \\
22 \\
15 \\
37 \\
4 \\
18 \\
9 \\
0 \\
9 \\
62 \\
16 \\
90\end{array}$ & $\begin{array}{r}7 \\
0 \\
2 \\
3 \\
7 \\
22 \\
0 \\
0 \\
7 \\
17 \\
7 \\
6 \\
15 \\
0 \\
5 \\
0 \\
2 \\
0 \\
28 \\
9 \\
16 \\
0 \\
0 \\
0 \\
12 \\
17 \\
5 \\
8 \\
14 \\
0 \\
5 \\
12 \\
0 \\
0 \\
42 \\
0 \\
37\end{array}$ & $\begin{array}{r}3 \\
0 \\
0 \\
0 \\
3 \\
12 \\
0 \\
0 \\
0 \\
8 \\
4 \\
0 \\
15 \\
0 \\
0 \\
0 \\
0 \\
0 \\
15 \\
6 \\
16 \\
0 \\
0 \\
0 \\
0 \\
7 \\
7 \\
5 \\
10 \\
0 \\
0 \\
3 \\
0 \\
0 \\
23 \\
0 \\
22\end{array}$ & $\begin{array}{r}90 \\
79 \\
94 \\
76 \\
82 \\
92 \\
87 \\
84 \\
86 \\
87 \\
85 \\
84 \\
84 \\
92 \\
93 \\
91 \\
107 \\
96 \\
96 \\
96 \\
103 \\
82 \\
88 \\
77 \\
106 \\
88 \\
88 \\
84 \\
88 \\
82 \\
97 \\
88 \\
83 \\
71 \\
65 \\
86 \\
91\end{array}$ & $\begin{array}{r}118 \\
108 \\
106 \\
133 \\
100 \\
113 \\
102 \\
105 \\
91 \\
112 \\
126 \\
85 \\
115 \\
115 \\
103 \\
110 \\
138 \\
140 \\
137 \\
130 \\
104 \\
91 \\
91 \\
115 \\
114 \\
109 \\
106 \\
109 \\
109 \\
115 \\
94 \\
133 \\
117 \\
77 \\
114 \\
114\end{array}$ & $\begin{array}{l}108 \\
138 \\
112 \\
120 \\
160 \\
121 \\
135 \\
127 \\
130 \\
145 \\
136 \\
126 \\
125 \\
133 \\
140 \\
133 \\
118 \\
128 \\
166 \\
158 \\
157 \\
123 \\
137 \\
127 \\
124 \\
134 \\
153 \\
131 \\
128 \\
149 \\
139 \\
136 \\
114 \\
123 \\
100 \\
129 \\
157\end{array}$ & $\begin{array}{l}120 \\
109 \\
106 \\
123 \\
145 \\
155 \\
107 \\
112 \\
133 \\
145 \\
136 \\
120 \\
120 \\
105 \\
125 \\
140 \\
100 \\
117 \\
140 \\
150 \\
141 \\
124 \\
136 \\
115 \\
117 \\
104 \\
152 \\
125 \\
128 \\
128 \\
165 \\
151 \\
105 \\
146 \\
100 \\
122 \\
160\end{array}$ & $\begin{array}{r}156 \\
97 \\
107 \\
126 \\
124 \\
163 \\
94 \\
94 \\
99 \\
109 \\
112 \\
117 \\
95 \\
98 \\
100 \\
130 \\
83 \\
106 \\
115 \\
121 \\
120 \\
111 \\
136 \\
114 \\
101 \\
97 \\
122 \\
108 \\
119 \\
105 \\
103 \\
112 \\
103 \\
129 \\
120 \\
117 \\
117\end{array}$ & $\begin{array}{r}136 \\
94 \\
97 \\
123 \\
112 \\
121 \\
91 \\
88 \\
107 \\
88 \\
99 \\
83 \\
83 \\
75 \\
98 \\
120 \\
80 \\
89 \\
89 \\
72 \\
104 \\
84 \\
111 \\
91 \\
86 \\
86 \\
106 \\
112 \\
124 \\
85 \\
103 \\
91 \\
76 \\
117 \\
106 \\
90 \\
86\end{array}$ & $\begin{array}{r}100 \\
71 \\
94 \\
112 \\
66 \\
92 \\
94 \\
86 \\
89 \\
84 \\
97 \\
80 \\
69 \\
74 \\
90 \\
95 \\
93 \\
76 \\
82 \\
58 \\
91 \\
71 \\
98 \\
93 \\
78 \\
80 \\
106 \\
115 \\
118 \\
82 \\
76 \\
87 \\
76 \\
115 \\
97 \\
88 \\
97\end{array}$ & $\begin{array}{r}71 \\
97 \\
103 \\
60 \\
70 \\
94 \\
78 \\
84 \\
92 \\
97 \\
68 \\
74 \\
69 \\
100 \\
72 \\
95 \\
83 \\
71 \\
67 \\
90 \\
77 \\
105 \\
90 \\
76 \\
83 \\
103 \\
121 \\
111 \\
70 \\
76 \\
82 \\
75 \\
100 \\
83 \\
83 \\
92\end{array}$ & $\begin{array}{r}80 \\
82 \\
91 \\
97 \\
54 \\
76 \\
86 \\
86 \\
86 \\
89 \\
84 \\
61 \\
82 \\
74 \\
74 \\
57 \\
85 \\
84 \\
71 \\
80 \\
67 \\
77 \\
95 \\
83 \\
74 \\
79 \\
76 \\
124 \\
103 \\
73 \\
73 \\
73 \\
73 \\
96 \\
93 \\
76 \\
86\end{array}$ \\
\hline
\end{tabular}


The results in the normal series are shown in Table II.

In the normal controls but not in the obese a significant inverse relationship $(r=-0.37$, $P<0.05$ ) was found between the peak and twohour value. All features of the tolerance curve, fasting, peak, two-hour values, and time of peak, were examined for a relationship with body weight. No correlation was found between weight and fasting, peak, and two-hour values in either the normal controls or the obese. In the normal controls there was a highly significant correlation between weight and time of the peak, the greater the weight the earlier the peak $(\mathrm{r}=-0.48, P<0.01)$. This relationship was paralleled by that seen in the galactose tolerance tests. No explanation can be offered for this phenomenon.

The post-gastrectomy subjects all showed peak values over $170 \mathrm{mg} . / 100 \mathrm{ml}$. Their fasting levels were all normal except one (108 mg./100 ml.), and their mean two-hour value was $73 \mathrm{mg} . / 100$ $\mathrm{ml}$., the highest being $83 \mathrm{mg} . / 100 \mathrm{ml}$.

The borderline obese group all gave results within normal limits.

Seven of the frankly obese subjects showed some abnormal feature in their curves. Six had a fasting level above $107 \mathrm{mg}$. $/ 100 \mathrm{ml}$. (none in the control series), three had abnormally high peaks, and two showed abnormally high two-hour values. Three of the remaining 11 had peaks higher than $160 \mathrm{mg}$. $/ 100 \mathrm{ml}$. compared with four of 37 normals.

The full data on all subjects included in this investigation are given in Tables I-VI.

\section{Constancy of the Glucose Tolerance Curve}

Gross discrepancies between repeat tolerance curves have been reported by Lennox (1927) and

TABLE $\mathrm{V}$

RESULTS OF PARALLEL GALACTOSE AND GLUCOSE TOLERANCE TESTS IN OBESE AND BORDERLINE SUBJECTS

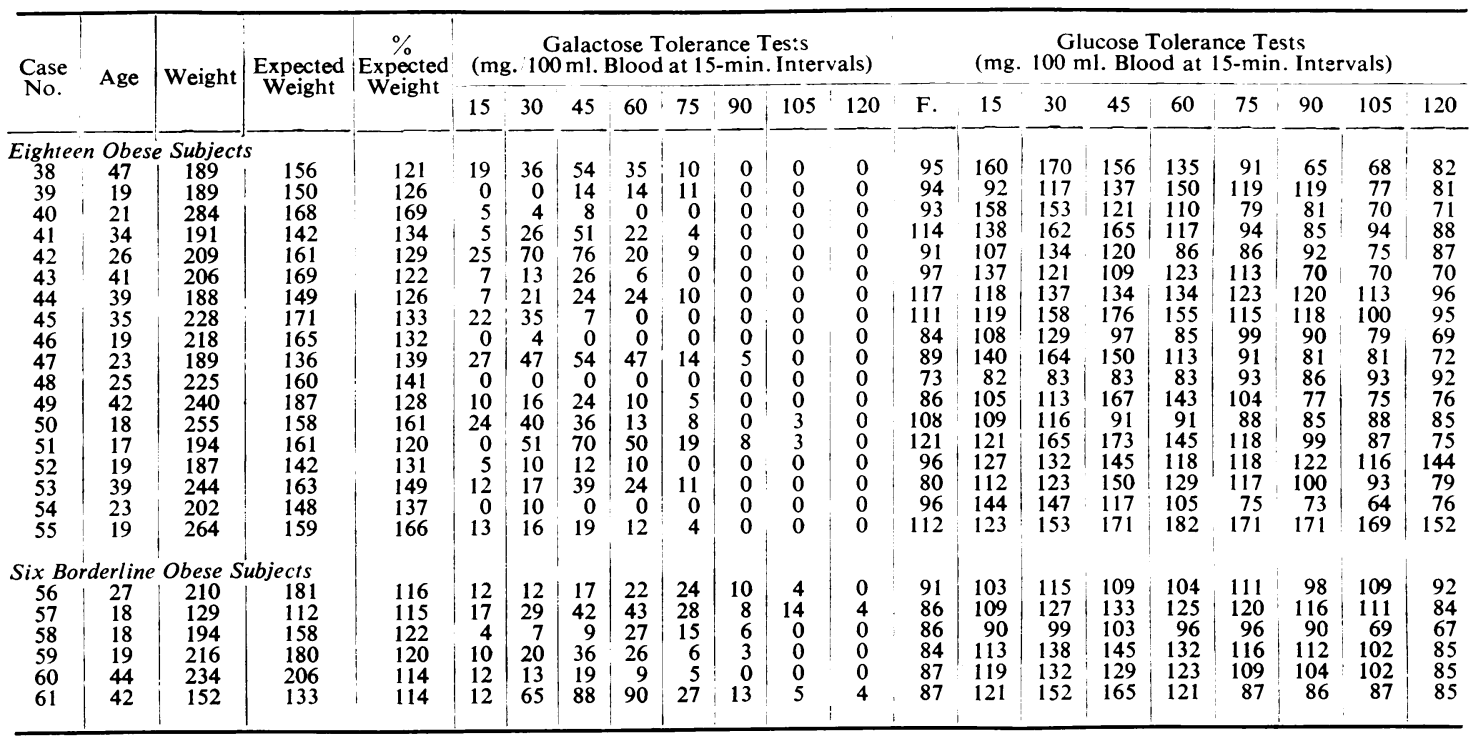

TABLE VI

PARALlel GALACTOSE AND GLUCOSE TOLERANCE IN POST-GASTRECTOMY PATIENTS

\begin{tabular}{|c|c|c|c|c|c|c|c|c|c|c|c|c|c|c|c|c|c|c|c|c|c|}
\hline \multirow{2}{*}{$\begin{array}{l}\text { Case } \\
\text { No. }\end{array}$} & \multirow{2}{*}{ Age } & \multirow{2}{*}{ Weight } & \multirow{2}{*}{$\begin{array}{l}\text { Expected } \\
\text { Weight }\end{array}$} & \multirow{2}{*}{$\begin{array}{c}\% \\
\text { Expected } \\
\text { Weight }\end{array}$} & \multicolumn{8}{|c|}{$\begin{array}{c}\text { Galactose Tolerance Tests } \\
\text { (mg. } 100 \mathrm{ml} \text {. Blood at } 15 \text {-min. Intervals) }\end{array}$} & \multicolumn{9}{|c|}{$\begin{array}{c}\text { Glucose Tolerance Tests } \\
\text { (mg. } 100 \mathrm{ml} \text {. Blood at } 15 \text {-min. Intervals) }\end{array}$} \\
\hline & & & & & 15 & 30 & 45 & 60 & 75 & 90 & 105 & 120 & F. & 15 & 30 & 45 & 60 & 75 & 90 & 105 & 120 \\
\hline $\begin{array}{l}62 \\
63 \\
64 \\
65 \\
66 \\
67 \\
68\end{array}$ & $\begin{array}{l}35 \\
30 \\
46 \\
42 \\
41 \\
52\end{array}$ & $\begin{array}{l}147 \\
152 \\
144 \\
140 \\
129\end{array}$ & $\begin{array}{l}188 \\
156 \\
174 \\
181 \\
156\end{array}$ & $\begin{array}{l}78 \\
97 \\
83 \\
76 \\
86\end{array}$ & $\begin{array}{l}67 \\
54 \\
66 \\
79 \\
56\end{array}$ & $\begin{array}{r}120 \\
115 \\
128 \\
97 \\
111 \\
79 \\
100\end{array}$ & $\begin{array}{l}95 \\
87 \\
88 \\
81 \\
84\end{array}$ & $\begin{array}{r}51 \\
57 \\
41 \\
49 \\
36 \\
130 \\
38\end{array}$ & $\begin{array}{l}28 \\
10 \\
19 \\
90 \\
16\end{array}$ & $\begin{array}{r}13 \\
7 \\
16 \\
0 \\
9 \\
46 \\
8\end{array}$ & $\begin{array}{r}0 \\
0 \\
7 \\
14 \\
0\end{array}$ & $\begin{array}{l}3 \\
0 \\
0 \\
0 \\
0 \\
9 \\
0\end{array}$ & $\begin{array}{r}76 \\
73 \\
78 \\
108 \\
94 \\
101 \\
99\end{array}$ & 137 & $\begin{array}{l}178 \\
173 \\
186 \\
192 \\
222 \\
172 \\
244\end{array}$ & 132 & $\begin{array}{r}110 \\
92 \\
81 \\
110 \\
121 \\
122 \\
103\end{array}$ & 53 & $\begin{array}{l}69 \\
53 \\
77 \\
82 \\
69 \\
86 \\
66\end{array}$ & 59 & $\begin{array}{l}62 \\
72 \\
64 \\
73 \\
80 \\
83 \\
78\end{array}$ \\
\hline
\end{tabular}


Freeman, Looney, and Hoskins (1942). Himsworth (1935) and Goto (1955) have on the contrary shown identical curves in repeat tests.

Eight subjects have been submitted to repeat tests. One was a "normal obese" individual and showed an impairment of tolerance, and the remaining seven were laboratory staff included in the normal control series. Although some showed close agreement between curves, others showed marked discrepancies, but, apart from one high fasting level and one secondary peak at one and three-quarter hours, all curves in the seven normal controls remained well within normal limits (Fig. 2).

\section{Discussion}

The galactose results in normal subjects are compared in Table III with other normal series where a $40 \mathrm{~g}$. dose of galactose was used. The great variation between workers can probably be accounted for by the techniques of estimation. The results of this series accord closely with those of Stenstam (1946). He found the range of peak values to be $18-108 \mathrm{mg}$./ $100 \mathrm{ml}$. (15-110 mg. $/ 100 \mathrm{ml}$. in this series), the average peak $58 \mathrm{mg}$. $/ 100 \mathrm{ml}$. (62 mg./ $100 \mathrm{ml}$.), and the average time of the peak 50 minutes (53 minutes).

When allowance is made for the differing details of performance and techniques of blood glucose estimation, the glucose tolerance results are found to be in accord with those of other "normal" series (Evensen, 1942; Mosenthal and Barry, 1950; Moyer and Womack, 1950).

The inverse relationship shown between the peak and the two-hour value would appear an important feature of the normal
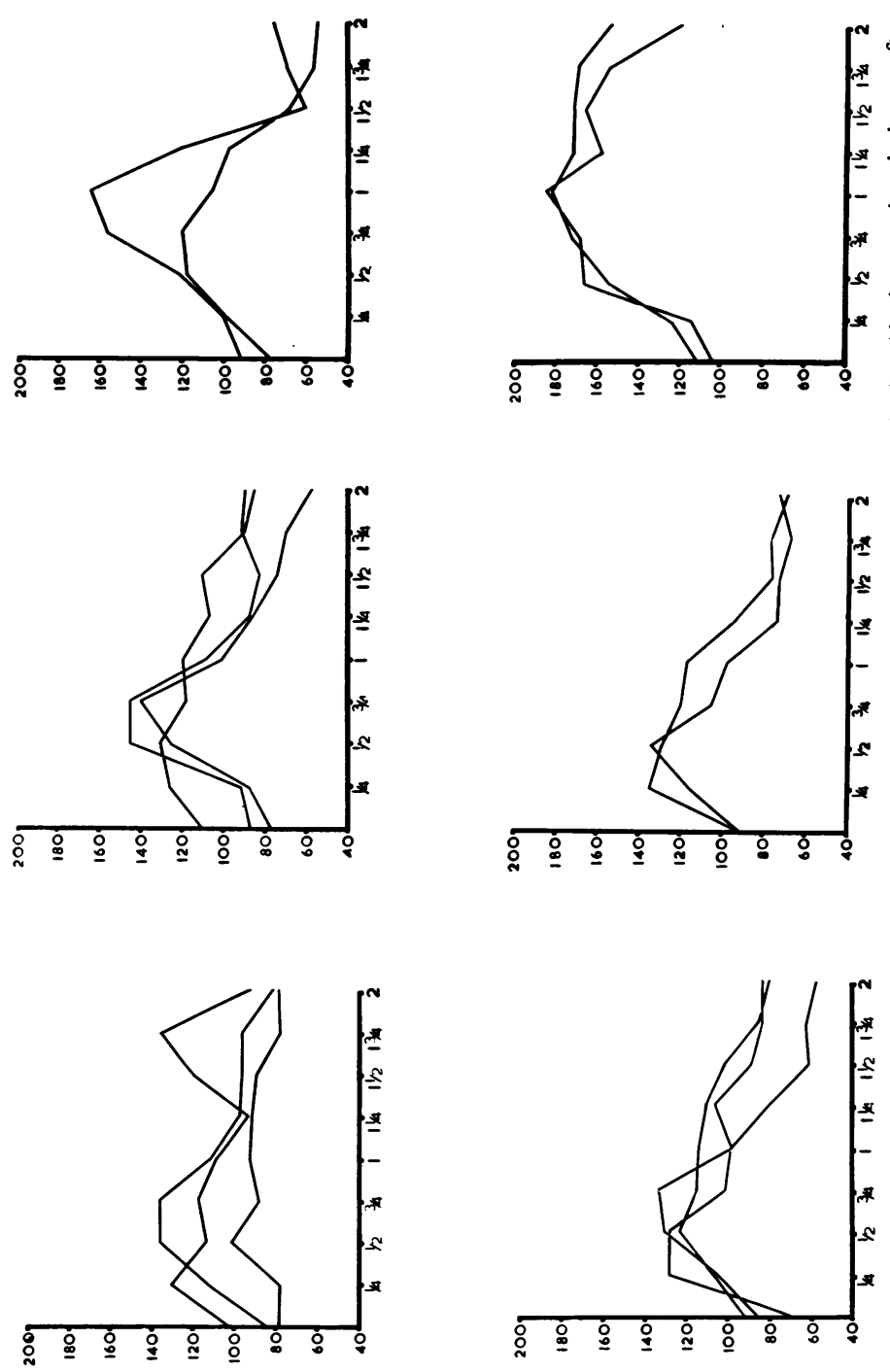

8
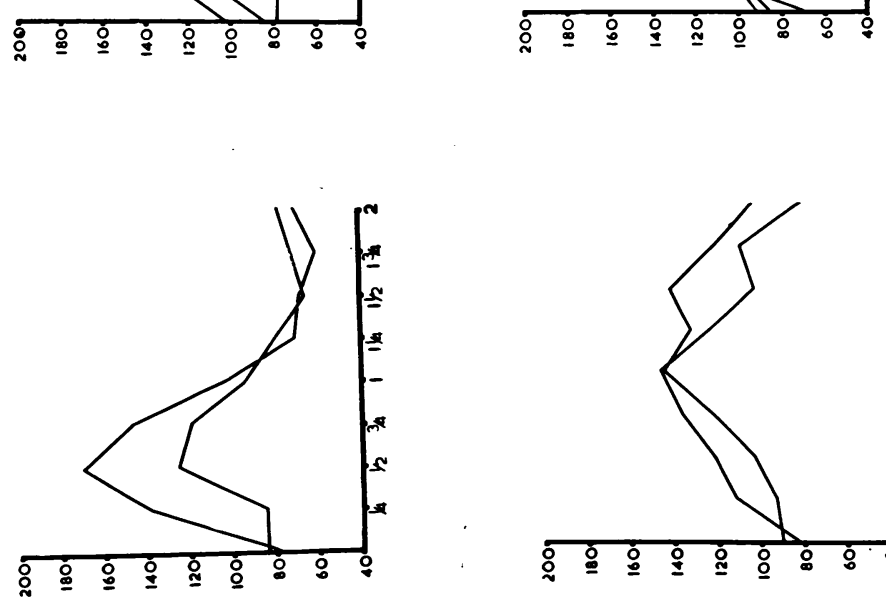
glucose tolerance curve. In application a peak value slightly exceeding normal limits combined with a low normal two-hour value or a two-hour level just above the accepted upper limit, but following a low peak concentration, may be regarded as normal, whereas a "high normal " peak and a "high normal" two-hour value may indicate impaired tolerance. An examination of the glucose tolerance tests performed in post-gastrectomy patients yields evidence in support of this.

Knowledge of the peak concentration is thus shown to be of value in assessing tolerance contrary to recently expressed opinions (Mosenthal and Barry, 1950 : Moyer and Womack, 1950 : Friend, 1951: Duncan, 1952). The peak value would seem to be a reasonably constant feature of the tolerance curve, the coefficient of variation (standard deviation expressed as a percentage of the mean being $9.6 \%$ as compared with $9.8 \%$ for the fasting values and $15.8^{\circ}$ " for the two-hour values).

Statistical examination shows no correlation between peak values of glucose and galactose in the normal control series. Close correlation, however, could not be expected since even when repeat tolerance tests are performed with the same sugar considerable variation is encountered. Furthermore, each value is the resultant of two main factors, the rate of absorption and the rate of removal from the blood. The rate of absorption of galactose is thought to be similar to that of glucose, but its removal from the blood is not

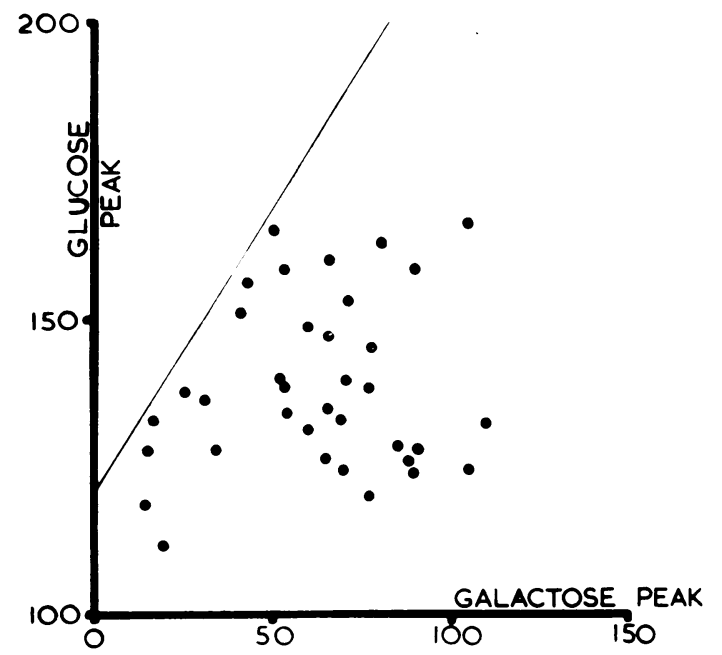

FIG. 3.-Scatter diagram of glucose and galactose peak values in normal individuals. (Blood sugar values in $\mathrm{mg} .100 \mathrm{ml}$.) Low galactose peaks were invariably associated with low glucose peaks. influenced by the same factors as affect the removal of glucose.

If the normal subjects with low galactose peaks are considered, it is found that all except one had a low glucose peak, although high galactose peaks are not necessarily associated with high glucose peaks (Fig. 3). This finding is in accord with the principle that when hepatic function is normal the galactose tolerance curve gives an indication of the rate of absorption of glucose. The homeostatic mechanism for glucose in the normal is able to compensate to greater or lesser degree for rapid absorption with more rapid removal, and, where absorption is fast, an active mechanism may result in a comparatively low peak. Where absorption is slow, little homeostatic activity is required to achieve a low peak, and hence except in subjects with impaired tolerance low glucose peaks are consistently found.

In patients who have had a partial gastrectomy, the gastro-jejunal anastomosis results in glucose solutions rapidly reaching the small intestine, which is the main site of sugar absorption. This is the explanation given for the consistently high glucose tolerance peak levels seen in most of these patients. Seven cases were examined, and, as expected, very significantly higher galactose tolerance peak values were found than in the normal control series. This suggests that peak galactose levels do mirror the rate of glucose absorption, particularly when the rate of absorption is considerably altered from the average normal. The gastrectomy cases were all under expected weight (mean $84 \%$ expected weight, range $76 \%-97 \%$ ), and for this reason a dose-body weight relationship could be suggested as partly responsible for the finding of high peak galactose levels. In view of the lack of correlation between galactose peak level and body weight within the series of normal controls and obese subjects, this appears unlikely. An analysis of covariance of galactose peak and body weight over all the groups studied shows that the galactose peaks in the post-gastrectomy patients are in fact higher than would be expected from their body weight.

Compared with the results found in the normals and post-gastrectomy series a marked divergence of glucose and galactose results is seen in the obese. Slow absorption of glucose in the obese would tend to mask impairment of tolerance assessed by the oral test. If the low galactose figures do in fact reflect slow absorption of glucose, then it seems probable that a high proportion of these "normal" obese individuals had impaired glucose tolerance, since they reach the 
borderline of abnormality in spite of slow absorption. Here again a possible alternative explanation would be a galactose dose-body weight relationship, but as with the gastrectomy cases this is unlikely and for the same reason.

It seems that obesity (excessive adipose tissue) as opposed to actual body mass is the determining factor in the low galactose peaks observed in the obese. It is possible that adipose tissue can remove galactose from the blood in a manner comparable with the liver. Bansi (1953) has shown in certain obese subjects that glycogen is laid down excessively in fat after the ingestion of glucose. Nevertheless slow absorption seems the more likely cause of the low galactose peaks and this receives support from certain other observations. Strang and McClugage (1931) investigated the specific dynamic action of a protein meal in normal and obese individuals. They showed that the total heat effect was similar but that in the obese the effect was delayed, the peak being lower and persisting over a longer period. Booth and Strang (1936) showed that in normals there was a rise in skin temperature after a protein meal. In the obese this was delayed and diminished. All these findings could be explained by a slow rate of absorption in the obese.

\section{Summary and Conclusions}

The assessment of glucose tolerance using the oral test is complicated by the variable rate of absorption which may occur in the intestinal tract. The galactose tolerance test has been proposed as a means of indicating the rate of absorption of glucose.

Glucose and galactose tolerance tests have been performed on 37 normal controls, seven postgastrectomy patients, 18 obese, and six borderline obese subjects. A modified method of blood galactose estimation has been employed.

Normal values in oral glucose and galactose tolerance have been reported and attention has been drawn to the inverse relationship which normally exists between peak and two-hour blood concentrations in the glucose test. Some relationship was noted between glucose and galactose curves performed in the same individual, but this was not a close one. Repeat glucose tests in the same individual have been shown to reveal marked variations.

Since a fixed dose of sugar was employed in both tolerance tests the tolerance data were examined for variations with body weight, but none was found. A surprising inverse relationship was shown to exist between the time of the peak and body weight in both glucose and galactose tolerance tests. No explanations could be offered.

Tolerance tests in post-gastrectomy patients revealed "lag" glucose and "lag" galactose curves ; in each case they closely resembled one another. These findings were considered to support the proposed use of the galactose tolerance test to indicate the rate of absorption of glucose.

Seven of 18 obese subjects showed some abnormality in the glucose tolerance test. There was a very marked trend for galactose tolerance curves to be low. It is suggested that in obesity the rate of absorption is slow in the intestinal tract and that this tends to mask impaired glucose tolerance when it is assessed using the oral test.

\section{A P P E N D I X Estimation of Blood Galactose}

The method used was a modification of that of King (1951).

Reagents.-The following are required:

(1) Sodium Sulphate-Sodium Tungstate Solution.This is made up of $88 \mathrm{ml} .3 \%$ sodium sulphate, and $12 \mathrm{ml} .10 \%$ sodium tungstate.

(2) Yeast Suspension.-Yeast (less than two weeks old preserved in the refrigerator), $2 \mathrm{~g}$., is washed three times in distilled water and suspended in $10 \mathrm{ml}$. of $3 \%$ sodium sulphate.

(3) $7 \%$ Copper Sulphate Solution.

(4) Galactose Standards.-(a) This is a stock solution (prepared every three months) of $1.1429 \mathrm{~g}$. of galactose in $1,000 \mathrm{ml}$. saturated benzoic acid. (b) The " 100 mg." working standard is freshly prepared before use by adding $5 \mathrm{ml}$. of the stock standard to $100 \mathrm{ml}$. of sodium sulphate-sodium tungstate solution. (c) The " $50 \mathrm{mg}$." working standard is a $1: 1$ dilution of the " $100 \mathrm{mg}$." standard in sodium sulphate-sodium tungstate solution.

(5) Folin and $W u$ Copper and Phosphomolybdic Reagents.-These are prepared as in the blood glucose method of Dische (1955).

Method.-(1) The samples are arranged as follows:

\begin{tabular}{|c|c|c|c|c|}
\hline & \multirow{2}{*}{ Test } & \multirow{2}{*}{ Blank } & \multicolumn{2}{|c|}{ Standards } \\
\hline & & & " $100 "$ & “ $50 "$ \\
\hline $\begin{array}{l}\text { Sodium sulphate-sodium } \\
\text { tungstate solution. } \\
100 \mathrm{mg} \text {. standard solution }\end{array}$ & $3.5 \mathrm{ml}$ & & $3.5 \mathrm{ml}$ & \\
\hline 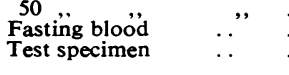 & $0.2 \mathrm{ml}$ & $0.2 \mathrm{ml}$. & $0.2 \mathrm{ml}$. & $\begin{array}{l}3.5 \mathrm{ml} \text {. } \\
0.2 \mathrm{ml} \text {. }\end{array}$ \\
\hline
\end{tabular}

(2) Add $1 \mathrm{ml}$. of yeast suspension, mix, and incubate in a water-bath at $37^{\circ} \mathrm{C}$. for 15 minutes.

(3) Remove, precipitate proteins with $0.3 \mathrm{ml}$. of $7 \%$ copper sulphate solution and centrifuge. 
(4) Remove $2 \mathrm{ml}$. of the filtrate into Folin and $\mathrm{Wu}$ tubes and proceed as for blood glucose estimation (Dische, 1955).

It is found that there is a linear relationship between reduction and galactose concentration between 10 and $100 \mathrm{mg}$. Below $10 \mathrm{mg}$. the relationship follows a curved line from the blank value to intersect the straight line drawn through 50 and $100 \mathrm{mg}$. standard readings at $10 \mathrm{mg}$. $/ 100 \mathrm{ml}$. galactose.

\section{REFERENCES}

Alsev, J. (1952). Klin. Wschr., 30, 406.

Althausen, T. L., and Stockholm, M. (1938). Amer. J. Physiol., 123,

Lockhart, J. C., and Soley, M. H. (1940). Amer. J. med. Sci., 199,342 .

Bansi, H.W.(1953). Ciba Foundation Colloquia on Endocrinology VI, p. 179. Churchill, London.

Barnes, C. G., and King, E. J. (1943). Quart. J. Med., 12, 129.

Bauer, R. (1906). Wien. med. Wschr., 56, 2537.

Beams, A. J., Free, A. H., and Glenn, P. M. (1941). Amer. J. dig. Dis., 8,415 .

Bollman, J. L., Mann, F. C., and Power, M. H. (1935). Amer. J. Physiol., 111, 483.

Booth, G., and Strang, J. M. (1936). Arch. intern. Med., 57, 533.

Cori, C. F. (1925). J.biol. Chem., 66, 691.

Cori, C. F. (1925). J.biol. Chem., 66, 691 23, 290

Darlington, W. A.. and Quastel, J. H. (1953). Arch. Biochem. Biophys., 43, 194.
Dische, S. (1955). J. clin. Path., 8, 253.

Duncan, G. G. (1952). Diseases of Metabolism, 3rd ed.. p. 816. Saunders, London.

Evensen, O. K. (1942). Acta med. scand., Suppl. cxxvi.

Freeman, H., Looney, J. M., and Hoskins, R. G. (1942). J. clin. Endocr., 2, 431

Friend, J. (195i). Lancet, 1, 207.

Goldner, M. G., and Clark, D. E. (1944). J. clin. Endocr., 4. 194.

Goto, Y. (1955). Metabolism, 4, 323.

Groen, J. (1937). J. clin. Invest., 16, 245.

Harding, V. J., and Grant, G. A. (1933). J. biol. Chem., 99, 629.

- and Van Nostrand, F. H. (1929). Ibid., 79, 497.

Himsworth, H. P. (1935). Clin. Sci., 2, 67.

Joslin, E. P., Root, H. J., White, P., and Marble, A. (1952). Treatment of Diabetes Mellitus, 9 th ed., p. 66 . Kimpton, London.

King, E. J. (1951). Micro-analysis in Medical Biochemistry, 2nd ed. p. 25. Churchill, London.

Kosterlitz, H. (1933). Z. ges. exp. Med., 90, 465.

Lennox, W. G. (1927). J. clin. Invest., 4, 331.

Levine, R., Goldstein, M. S., Huddlestun, B., and Klein, S. P. (1950). Amer. J. Physiol., 163, 70.

MacLagan, N. F. (1940). Quart. J. Med., 9, 151.

Mosenthal, H. O., and Barry, E. (1950). Ann. intern. Med., 33, 1175.

Moyer, J. H., and Womack, C. R. (1950). Amer. J. med. Sci., 219 161 .

Nissen, N. I. (1937). Ugeskr. Lag., 99, 427

Öhnell, R., and Höber, R. (1939). J. cell. comp. Physiol., 13, 161.

Park, C. R., and Johnson, L. H. (1955). Amer. J. Physiol., $182,17$.

Ricketts, H. T., Brunschwig, A., and Knowlton, K. (1945). Proc. Soc. exp. Biol. (N.Y.), 58, 254.

Smith, W. H., Fraser, R., Staynes, K., and Wilcox, J. M. (1953). Lancet, 2, 530.

Stenstam, T. (1946). Acta med. scand., Suppl. 177.

Strang, J. M., and McClugage, H. B. (1931). Amer. J. med. Sci.. 182, 49 . 